\title{
Preface to the ESPA-2012 special issue
}

\author{
Juan J. Novoa $\cdot$ Manuel F. Ruiz-Lopez
}

Published online: 27 April 2013

(C) Springer-Verlag Berlin Heidelberg 2013

This issue of Theoretical Chemistry Accounts contains a recollection of some of the work presented and discussed at the 8th edition of the Electronic Structure: Principles and Applications (in short, ESPA-2012). The ESPA events are biennial international research conferences organized within the activities of the Spanish Theoretical Chemistry groups that co-organize the Interuniversity Doctorate in Theoretical Chemistry and Computational Modeling. The main aim behind all ESPA conferences, shared by the organizers of ESPA-2012, is promoting scientific excellence and exchange of ideas among their Ph. D. students, in a friendly environment. ESPA-2012 follows previous events held in Madrid, San Sebastián, Sevilla, Valladolid, Santiago de Compostela, Palma de Mallorca, and Oviedo.

ESPA-2012 took place in Barcelona from the 26th up to the 29th of June 2012, in a magnificent location: the Auditorium of CosmoCaixa in Barcelona, the Science Museum created and supported by "La Caixa" savings bank in the hills that overlook Barcelona from the North. We all remember the superb auditorium facilities, together with its amazing views to the Science Museum and the city of

Published as part of the special collection of articles derived from the 8th Congress on Electronic Structure: Principles and Applications (ESPA 2012).

J. J. Novoa $(\bowtie)$

Departament de Química Física \& IQTCUB, Facultat de Química, Universitat de Barcelona, Av. Diagonal 645, Barcelona 08028, Spain

e-mail: juan.novoa@ub.edu

M. F. Ruiz-Lopez ( $\square)$

SRSMC, Theoretical Chemistry and Biochemistry Group,

University of Lorraine, CNRS,

54506 Vandoeuvre-les-Nancy, France

e-mail: Manuel.Ruiz@univ-lorraine.fr
Barcelona. The conference was organized by Prof. Juan J. Novoa (Chairman), helped by (al alphabetical order) Albert Bruix (Ph. D. student), Prof. Rosa Caballol, Marçal Capdevila (Ph. D. student), Dr. Mercè Deumal, Prof. Javier Luque, Dr. Iberio de P. R Moreira, Dr. Fernando Mota, Dr. Jordi Ribas-Ariño, Prof. Ramón Sayós, Dr. Carmen Sousa, and Sergi Vela (Ph. D. student). A picture of the Organizing Committee is displayed in Fig. 1.

ESPA-2012 was designed guided by three main principles: (1) passion for discovery, (2) scientific excellence, and (3) a friendly environment. For sure, all ESPA-2012 participants shared the same emotions beautifully described by Herman Melville in his "Moby Dick" book: “... but as for me, I am tormented with an everlasting itch for things remote. I love to sail forbidden seas, and land on barbarous coasts." Concerning our passion for Science, for sure, most ESPA-2012 participants went to Barcelona with the aim of reporting their discoveries while "sailing the Theoretical Chemistry and Computational Modeling seas," and also listening at other participant's reports. After all, modern scientific research is a cooperative effort, where it is still valid Isaac Newton's statement: "If I have seen further is by standing on the shoulders of giants."

In relation to excellence, it is sometimes stated that the quality of a conference can be measured, at least partially, by the stature of its invited speakers. Aiming at excellence, in ESPA-2012, we had as invited speakers some of the world leaders in the field of Theoretical Chemistry and Computational Modeling. Each one gave one of the nine Invited Plenary Talks: The Opening Plenary Talk was delivered by Prof. M. A. Robb (Imperial College London; Fellow of the Royal Society of Chemistry) and the Closing Plenary Talk was given by Prof. W. L. Jorgensen (Yale University, CT, USA, Co-editor of Journal of Chemical Theory and Computation). The remaining seven Invited 
Plenary Talks were presented (in alphabetical order) by Prof. Johan Aqvist (Uppsala University), Prof. Bjork Hammer (Aarhus University), Prof. Pavel Hobza (Institute of Organic Chemistry and Biochemistry), Prof. Frank Neese (Max Planck Institute for Bioinorganic Chemistry), Prof. Matthias Scheffler (Fritz Haber Institute), Prof. Sason S. Shaik (The Hebrew University), and Prof. Manuel Yañez (Universidad Autónoma de Madrid). Each Invited
Plenary Talk had an allocated time of $45 \mathrm{~min}$ (40 min of presentation, followed by $5 \mathrm{~min}$ of questions, that is, $40^{\prime}+5^{\prime}$ talks). Besides them, there were 25 Contributed Talks $\left(15^{\prime}+5^{\prime}\right.$ each), selected by the Organizing Committee among all propositions, and about 200 posters, also previously evaluated by the Organizing Committee. Two poster sessions were allocated for their presentation by one of their authors (each session lasting 2 hours).

Fig. 1 a Picture of the ESPA2012 Organizing Committee taken in the Main Entrance to the Chemistry Building of the University of Barcelona. Lower row (from left to right): J. J. Novoa, C. Sousa, R. Sayós, J. Ribas-Ariño, I. de P. R Moreira, M. Deumal; Upper row (from left to right): J. Luque, R. Caballol, A. Bruix, S. Vela, M. Capdevila, F. Mota. b ESPA2012: A cooperative work, illustrated by a picture of a sixfloor Human Castle, a Catalan tradition
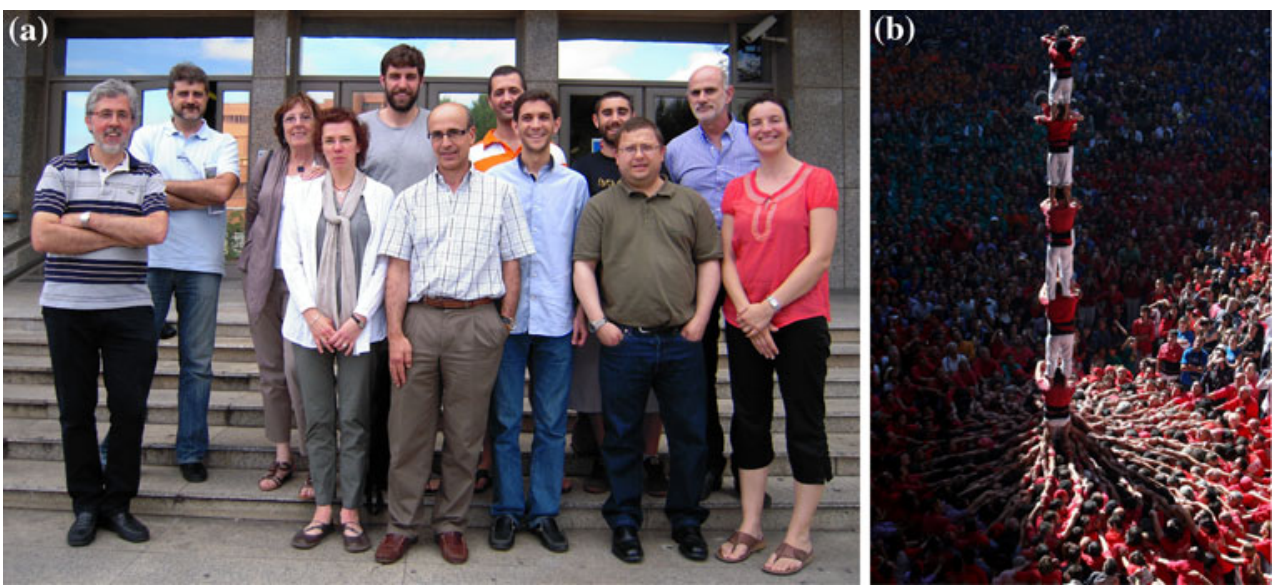

\begin{tabular}{|c|c|c|c|}
\hline \multirow{2}{*}{ Cosmocaixa } & & \multicolumn{2}{|r|}{ Wed., 27 / 6 / 2012} \\
\hline & $9: 00-9: 30$ & \multicolumn{2}{|r|}{ OPENING CEREMONY } \\
\hline \multicolumn{4}{|r|}{ ORAL SESSIONMI } \\
\hline Michael A. Robb & 9:30-10:15 & Plenary 1 & $\begin{array}{l}\text { Non-adiabatic Chemistry at the Conical Intersection Seam Studied With "On the fly" Quantum } \\
\text { Dynamics }\end{array}$ \\
\hline Ángel Martin Pendás & $10: 15-10: 35$ & \multirow{3}{*}{$\begin{array}{l}\text { Theory, methods } \\
\& \text { foundations } 1\end{array}$} & Fluctuation of electron populations and chemical bonding \\
\hline Coen de Graaf & $10: 35-10: 55$ & & The effect of thermal motion on the spectroscopic properties of $\mathrm{NiO}$ \\
\hline \multirow[t]{2}{*}{ Alessandro Erba } & $10: 55-11: 15$ & & $\begin{array}{c}\text { Temperature Effects on the Density Matrix of Crystals: An ab initio Monte Carlo Harmonic } \\
\text { Approach }\end{array}$ \\
\hline & $11: 15-11: 45$ & \multicolumn{2}{|r|}{ COFFEE BREAK } \\
\hline \multicolumn{4}{|r|}{ ORAL SESSION M2 } \\
\hline Johan Aqvist & $11: 45-12: 30$ & Plenary 2 & Cold-Adaptation of Enzyme Reaction Rates \\
\hline Alexandra T. P. Carvalho & $12: 30-12: 50$ & \multirow{3}{*}{$\begin{array}{l}\text { Biomolecular } \\
\text { modelling } 1\end{array}$} & Role of the amide groups in the tuning of redox reactions \\
\hline Carles Curutchet & $12: 50-13: 10$ & & Ultrafast light-harvesting dynamics in the PE545 photosynthetic antenna \\
\hline \multirow[t]{2}{*}{ Dan T. Major } & $13: 10-13: 30$ & & $\begin{array}{c}\text { Electrostatically Guided Enzyme Dynamics - the Root of Fidelity in a Promiscuous Terpene } \\
\text { Synthase: The Case of Bornyl Diphosphate Synthase }\end{array}$ \\
\hline & $13: 30-15: 30$ & \multicolumn{2}{|r|}{ LUNCH } \\
\hline & & \multicolumn{2}{|r|}{ ORAL SESSION T1 } \\
\hline Matthias Scheffler & $15: 30-16: 15$ & Plenary 3 & The random-phase approximation for the electron correlation energy and beyond \\
\hline Carmen J. Calzado & $16: 15-1635$ & \multirow{3}{*}{ Materials science 1} & $\begin{array}{l}\text { Magnetic interactions in polynuclear transition metal systems from wave function based } \\
\text { methods }\end{array}$ \\
\hline Johannes Gierschner & $16: 35-16: 55$ & & Tuning of Optical \& Photophysical Properties in Organic Crystals \\
\hline \multirow[t]{4}{*}{ José R.B. Gomes } & $16: 55-17: 15$ & & $\begin{array}{c}\text { The Early Stages of the Synthesis of Hybrid Mesoporous Organosilicas: DFT and Molecular } \\
\text { Dynamics Simulations }\end{array}$ \\
\hline & $17: 15-17: 45$ & \multicolumn{2}{|r|}{ COFFEE BREAK } \\
\hline & $17: 45-19: 00$ & \multicolumn{2}{|r|}{ POSTER SESSION P1 } \\
\hline & $20: 00-23: 30$ & & CULTURAL ACTIVITY: A NIGHT AT THE OPERA \\
\hline
\end{tabular}

Fig. 2 Detailed Wednesday 27 Program 


\begin{tabular}{|c|c|c|c|}
\hline \multicolumn{2}{|l|}{ Cosmocaixa } & \multicolumn{2}{|r|}{ Thu., 28 / 6 / 2012} \\
\hline & & \multicolumn{2}{|r|}{ ORAL SESSION M3 } \\
\hline Pavel Hobza & $9: 00-9: 45$ & Plenary 4 & Nonempirical, semiempirical and empirical interaction energies \\
\hline Slawomir J. Grabowski & $9: 45-10: 05$ & \multirow{3}{*}{$\begin{array}{l}\text { Theory, methods } \\
\& \text { foundations } 2\end{array}$} & The Description of Non-Covalent Interactions in Terms of Bent's Rule \\
\hline Enrique Sánchez Marcos & $10: 05-10: 25$ & & $\begin{array}{l}\text { A multitechnique approach to elucidate axial hydration of square-planar complexes of metal } \\
\text { cations }\end{array}$ \\
\hline Julia Contreras-Garcia & $10: 25-10: 45$ & & NCI: a new quantitative method for revealing non-covalent interactions \\
\hline \multirow[t]{2}{*}{ Manuel Yáñez } & $10: 45-11: 30$ & Plenary 5 & $\begin{array}{l}\text { Non-covalent interactions: From hydrogen bonds to beryllium bonds or the importance of } \\
\text { deformation }\end{array}$ \\
\hline & $11: 30-12: 00$ & \multicolumn{2}{|r|}{ COFFEE BREAK } \\
\hline & & \multicolumn{2}{|r|}{ ORAL SESSION M4 } \\
\hline Sason Shaik & $12: 00-12: 45$ & Plenary 6 & The Valence Bond way in Chemistry \\
\hline Gregori Ujaque & $12: 45-13: 05$ & \multirow{3}{*}{ Chemical reactivity 1} & AIMD approach to Homogeneous Catalysis: The Wacker and Shilov Reactions \\
\hline Carmen Barrientos & $13: 05-13: 25$ & & Searching for the Origin of Biomolecules in Space \\
\hline \multirow[t]{3}{*}{$\begin{array}{l}\text { Margarita I. Bernal- } \\
\text { Uruchurtu }\end{array}$} & $13: 25-13: 45$ & & Bromine Dissociation in aqueous clusters. The catalytic role of water \\
\hline & $13: 45-16: 00$ & \multicolumn{2}{|r|}{ LUNCH } \\
\hline & $16: 00-20: 00$ & \multicolumn{2}{|r|}{ CULTURAL ACTIVITY: EXCURSION } \\
\hline
\end{tabular}

Fig. 3 Detailed Thursday 28 Program

For didactic reasons, all presentations were grouped into one of the following four thematic areas that we have drawn on for the presentation of this TCAC Volume: [1] Theory, methods and foundations (TMF), [2] Chemical Reactivity (CR), [3] Biomolecular Modeling (BM), and (4) Materials Science (MS). In order to further facilitate the effort of the audience, they were presented in thematic sessions, constituted by one Plenary Talk and three Contributed Talks, whenever possible. There were two morning sessions, separated by a coffee break, on 3 days with scientific sessions (27, 28, and 29 of June) and two afternoon sessions, separated by another coffee break, on the 27th and also on the 29th. There was a first poster session on the afternoon of the 27th (posters of the thematic areas TMF and MS) and another on the afternoon of the 29th (poster of thematic areas $\mathrm{CR}$ and $\mathrm{BM}$ ).

It was in our stated aim to make the atmosphere of ESPA-2013 as friendly as possible. With this idea in mind, we prepared a rich social program, with events every day and non-overlapping in time with the scientific program. The ESPA-2012 Conference started in the afternoon of the 26th with the Registration and Welcome Party. All participants were asked to register at the Historical Building of University of Barcelona, located downtown Barcelona. Registration was followed by the first social activity: a Welcome Party that took place, in the late afternoon hours, under the shade of the old trees planted in the Historical Building gardens. All participants had a chance to meet old friends and make new ones, while enjoying live piano music and a snack served with wine or non-alcoholic beverages. The activities of the social program ended with a Conference Dinner on the 29th, in a restaurant overlooking Barcelona and with superb views over the city night-lights. In between these two events, on 27th, there was an "A night at the Opera" event for all participants interested on opera, which took place at the Barcelona Opera House (whose local nickname is "El Liceu"), where we watched and listened the start-up performance of "Pelléas et Mélisande," a Debussy's opera. On 28th, we all had a "paella" at the Barcelona Olympic Harbour, followed by an afternoon visit to the three most impressive Gaudi's architectural masterpieces located in Barcelona: "Parc Guell," "Sagrada Familia," and "La Pedrera." Besides these activities, lunch on the 27th and 29th was arranged by the Organizing Committee for all participants in a high-end restaurant located nearby CosmoCaixa Auditorium (a bus shuttle service was provided by the organization, both directions).

The scientific program of ESPA-2012 started in the morning of June 27, with the Opening Ceremony presided by the Chancellor of the University of Barcelona, Prof. Didac Ramirez. Afterward, we had the six morning sessions, two afternoon sessions, and two poster sessions, and their speakers and titles are shown in Figs. 2, 3, and 4 (for Wednesday 27, Thursday 28, and Friday 29). The scientific part of ESPA-2012 ended on the afternoon of June 29th 


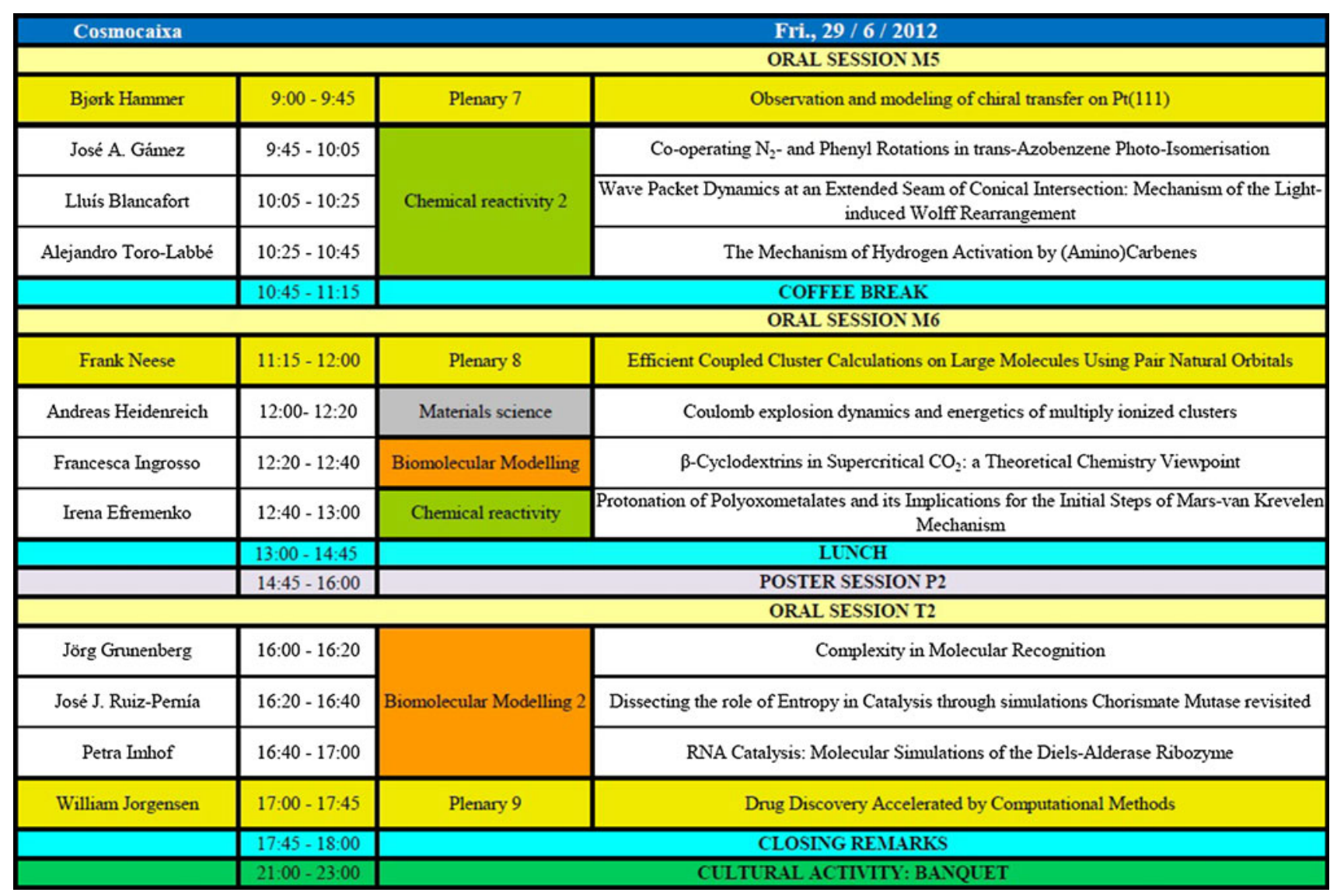

Fig. 4 Detailed Friday 29 Program

with the Closing Remarks Ceremony. The ceremony started with the presentation of the four poster prizes to their winners, one per each of the four thematic areas in which all posters were grouped (see above). Afterward, the Conference Chairman wished a safe trip back home to all participants and also strength for the difficult economic times still to come. The Closing Remarks Ceremony ended with a special "see you soon, friends," using the first two verses of a beautiful farewell Catalan song: "If you tell me farewell, I wish that it would be in a clear and bright day." Then, following the traditions of this part of Spain, all participants had a chance to say farewell while drinking a cup of Catalan cava, served chilled in the gardens of CosmoCaixa.

There were 261 participants at ESPA-2012, 165 of them with a Ph. D. degree and $96 \mathrm{Ph}$. D. students. Most participants were Spanish. All others came from 20 different countries (in alphabetical order, Argentina, Algeria, Austria, Brazil, Bulgary, Chile, Czech Republic, Denmark, France, Germany, India, Israel, Italy, Mexico, New Zealand, Portugal, Russia, Sweden, United Kingdom, and the United States of America).

As you have seen, we all enjoyed the meeting at ESPA2012: Lots of good scientific ideas, time to talk with our old and new friends about them, time to enjoy visiting Barcelona and some of its cultural highlights.

We hope to see you again at the next ESPA, ESPA2014 ! In the meantime, our best wishes to all with a final quote, attributed to Albert Einstein: "The most beautiful thing we can experience is the mysterious. It is the source of all true Art and all Science." 